\title{
An Examination and Evaluation of Multi-Level Governance During Migration Crisis: The Case of Slovenia ${ }^{1}$
}

\author{
Danila Rijavec \\ University of Ljubljana, Faculty of Social Sciences, Slovenia \\ danila.rijavec@gmail.com \\ Primož Pevcin \\ University of Ljubljana, Faculty of Administration, Slovenia \\ primoz.pevcin@fu.uni-lj.si
}

ABSTRACT

Paper presents the value added to the analysis of the functioning of multi-level governance in the context of EU. Furthermore, it contributes to the small state studies, as the mitigation of crisis from the perspective of small state is analysed. The aim of the research was to determine whether the multi-level governance during the large-scale crisis was successful and what factors affected the level of success. The analysis utilizes of the case study method, where the crisis responses during the peak of Western Balkan migration route and Slovenia as a small state on Schengen border serve as examples of examination and evaluation. Results show unsuccessfulness of multi-level governance during the crisis, with mostly top-down direction of decision-making, and particularly the subnational level being poorly involved into the process. In addition, also layering of policy creation and implementation can be observed. The results of the analysis also pointed out that the multi-level governance in the case of migration crisis on the Western Balkans Route can be positioned as the type 1 governance, if we follow the outline of Hooghe and Marks (2003). The results indicate that unsuccessful multi-level governance had negative impacts on managing the crisis, as well as on perceptions about EU and Schengen Zone. This study is novel in its content, as it represents the first examination and evaluation of multi-level governance during the EU migration crisis, where Western Balkan route and Slovenia as small state on the outer Schengen zone border serve as a case study for the evaluation.

Keywords: crisis management, migration crisis, multi-level governance, evaluation, small state, Slovenia.

JEL: D72, H12, H77

1 This publication is published with the support of the Erasmus+ programme of the European Union. It is part of the Jean Monnet Networks project Navigating the Storm: The Challenges of Small States in Europe. 


\section{Introduction}

During the last decade, the European Union is exposed to one the biggest migration crisis since the World War II. Migrants enter EU through several routes, some of them are difficult and extremely dangerous ones. The entry points are Member States, which are geographically close to the Mediterranean Sea, but the target destinations are richer European countries such as e.g. Germany and Sweden. Frontex (2017) lists eight main migration routes to the target points counties, which mostly extend along the southern and south-eastern part of the EU. This research will focus on the Western Balkans route, which was particularly active for one year in the period from 2015 to 2016 and extends through the countries of Turkey, Greece, Macedonia, Serbia, Hungary, Slovenia, Austria and Germany (BBC News, 2015).

Slovenia was directly affected by the migrant crisis in October 2015, right after the closure of the Hungarian border, when migrants immediately started to enter in order to pass another transit country and to reach out their final destination. The first registrations of migrants in Slovenia took place on October 16, 2015 (Republika Slovenija, Ministrstvo za notranje zadeve, 2017b and Republika Slovenija, Ministrstvo za notranje zadeve, 2017c), and then the country coped with the group of transit migrants until the beginning of March of 2016, when the western Balkan route officially closed.

Since the interest in staying and integrating in the system was not indicated by migrants, Slovenian authorities tried to direct them as quickly and efficiently as possible to Austria. Slovenia thus accepted migrants on the border with Croatia, carried out the registration process, offered them health and other necessary care, and then handed them over at the northern border to Austrian authorities. During the half year period, Slovenia allowed entrance to approximately half of million migrants, which accounts for a quarter of its own population (Republika Slovenija, Ministrstvo za notranje zadeve, Policija, 2015 and Republika Slovenija, Ministrstvo za notranje zadeve, Policija, 2016a).

Slovenia adopted the EU solidarity answer from the very beginning on, but still in addressing migrant issues, Slovenia is committed to respect and implement supranational and national legislation and the rules and procedures for protecting external Schengen border. It was clear that the situation could not be handled only by the national level, but it required a diverse range of organizations to work closely together at many different operational and decision-making actions. Namely, tackling this crisis required efficient multi-level governance, which represents also the backbone of administrative structure of the EU.

The aim of the paper is to examine and evaluate the multilevel governance in tackling migration crisis of 2015-16 with specific focus on Slovenia. The research shows many shortcomings of it and the core research question of the paper is, why and what factors contributed to the collapse of multi-level governance. Paper uses predominantly qualitative approach, which is also prevalent in the literature (Zincone and Caponio, 2004). This approach is based on 
the analysis of various official documents and notes, media interviews and participant observations, the analysis of newspaper proceedings and opinion pools, but it also incorporates relevant data and indicators, where applicable and available.

The paper is organized as follows. First, it introduces fundamental theoretical considerations and brief literature review. Second, it introduces the methodology used to reach the results of the research. Then, results of the research are presented. Subsequently, in the discussion part the analysis of the results will take place. Finally, the article draw conclusion regarding the multi-level governance of the migrant influx in Slovenia with addressing the shortcoming and suggestions for improvements.

\section{Theoretical Considerations and Literature Review}

The first references of the model of multi-level governance date back to 1993, when Marks (1993, p. 401-402) presented his model as a result of the centrifugal process in which the decision-making processes are directed away from the national level in two possible directions - up to supranational or down to subnational level. Power strives away from the national level, mainly as a result of the contemporaneous process of European integration and regionalism (Hooghe, 1996). Later on, Hooghe and Marks (2003, p. 234) strived for radical changes in governance by jointly defining multi-level governance as a permanent system of negotiations between nested actors through different levels. Over the years, the definition has been complemented by many authors and led to defining it as a strongly interconnected network, involving several different actors. Networking and co-operation is based on a strong and transparent dialogue, on which external factors rarely affect and is not marked by differences in space or geographical distance. The most important achievement of the model is that no decision-making level or no actor is overriding to another, the model therefore creates a common interdependence in decision-making and mutual equivalence (Stephenson, 2013). Decision-making should be more bottom-up oriented in order to provide more flexibility at the local level and boosting the creation of local policies (Tasan-Kok and Vranken, 2011).

The administrative functioning of the EU is based on the multi-level governance principles, and the stability of the union is based on the tight cooperation (Moussis, 1999). In the same line as the tight cooperation helps to solve the day-to-day issues, it should also address solving issues of a large-scale. Crisis of a large-scale often immerge very fast and can leave long-term consequences if handling the situation is not adequate. In particular, multi-level governance can be challenged by large-scale crisis issues, and literature review can provide numerous evidence. The sensitivity in this case can be tackled since management of the situation depends on many actors on different levels and for so no clear command is pre-established on the actor's responsibility boundaries or on the directions of the crisis management. The possibility for emerging social, political and economic conflict is hardly avoidable. By 
the uniqueness of every large-scale crisis maintaining the situational awareness and the ability to effectively improvise on the recognised novelty has an important role for the integrated execution in real time by potentially same inclusion of the levels (Howitt and Leonard, 2006).

Large-scale crisis management has been discussed by many scientists and the topic entered the public discourse. Examples as by the authors Howitt and Leonard (2006) on improving disaster response capabilities caused by the Hurricane Katrina, by Tanimura and Yoshikawa (2014) on using the standardization to improve crisis management essential developed on the example of the Great East Japan Earthquake, by the template for leading crisis operations named National Incident Management System (NIMS) launched in 2001 by the Department of Homeland Security of the United States of America and many others scholars are of a great help to governments in order to properly prepare and predict unnecessary negative situations. All three models named above examine different situation and for so, different perspective and solution on preparing and solving the large-scale crisis is addressed. Generally looking they all share the concluding idea presented by Tanimura and Yoshikawa (2014): observe, orient, decide and act. Their conceptual framework is beneficial for including actors on many levels to identify the chaotic situation in an early stage and clarify the strategic and operational management of the crisis. A prompt response of the actors leads to an effective and efficient crisis respond and prevent unexpected event to deepen the confusion and later on the potential damage.

Recently, a modest stream of literature on the multi-level governance of migration and integration policies within EU has emerged, although mainly policies are discussed, and not crisis situation. Interestingly, the research points out that in particular immigration policy-making is characterized by struggle among supranational and national level on the amount of discretion national level has in interpreting EU directives, and this field has been earmarked with resulting complex relations among all levels of governance. In addition, substantial fragmentation of policy-making and implementation has been observed in this area, where different levels and layers of government develop often structurally unconnected policies (Scholten and Penninx, 2016). This might suggest so-called decoupled relations between government levels, where policies are dissociated and even contradictory between levels, finally leading to inevitable conflicts (Jǿrgensen, 2012).

The examination and evaluation of multi-level governance has been addressed also from the perspective of new member states and small states, and several different pattern have evolved. For instance, Kluvankova-Oravska and Chobotova (2010) argue that multi-level governance from the perspective of Central and Eastern European countries is characterized by a prevailing hierarchical structure, and there is a mismatch between old hierarchical structures and new institutions developed during and after the period of transition, causing often vertical coordination problems. Similarly, the evaluation from the perspective of small states also reveals some interesting find- 
ings. The review of existing research points out that in the small EU countries hardly any involvement of subnational actors in policy-making processes or in networking can be observed and in those countries subnational actors are rather weak partners to the national level (Kull and Tatar, 2015). Consequent$l y$, there is a clear need to add case studies on the evaluation of multi-level governance, targeting these two above mentioned specific context, which this paper is aiming for.

\section{Data and Methodology}

The research is based on the qualitative methodology, and case study analysis serves as basic approach. The methodology of the paper uses different techniques while assessing the efficiency and effectiveness of the multi-level governance: first, the research adopts the top-down perspective to analyse the relations; second, multi-level governance is examined on the basis of four most tackled issues at the time of migration crisis in Slovenia, which are assembled in four parameters; third, the situation is evaluated by the model of predictable challenges of multi-level governance (Tasan-Kok and Vranken, 2011) and by the model of shortcomings of the multi-level governance (Hurrelmann and DeBardeleben, 2009). Moreover, paper positions the specific situation into one of the two types of multi-level governance, and finally, paper presents recommendations for potential future improvements. Each technique is further elaborated hereinafter. For a lucid overview, the methodology of the paper is graphically presented below.

Figure 1: Graphical illustration of methodology
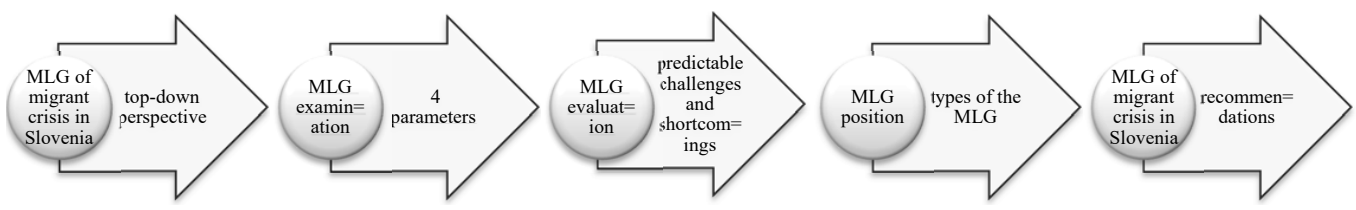

Source: The authors' elaboration

The concept of multi-level governance is examined on the basis of the migrant influx occurred on the Western Balkans Route during the period 201516. The context of the analysis is based on Slovenian perspective, and success in tackling the migration crisis is examined from the multi-level governance perspective. That is, the conceptual framework of the multi-level governance serves as the basis for the case study analysis on the crisis responses and management at all three levels that actively participated in managing the migrant influx in Slovenia; supranational (EU), national and subnational level. Furthermore, when analysing the relations between the levels, the top-down perspective was considered, specifically, the focus was given to the analysis of policy implementation and the evaluation of outcomes, as already previously introduced by Zincone and Caponio (2004). As the clear-cut system of command and control of the supranational and national elites is established 
within the European Union, the subnational governments and street-level officials clearly depart from both when creating the policies. This specific case study analyses the relations among various actors from the perspective, how the extent of subnational level's decision-making complies with that at the national and supranational level.

The involvement in managing the migration crisis is examined at each level of governance through the following parameters: solidarity response, registration and accommodation centres, additional technical controls at the internal Schengen border, and building the technical barriers at the external Schengen border (that is, on the border with Croatia). The parameters are selected on the basis of most challenging issues in Slovenia during the crisis. The examination reflects four issues that most notably impacted the migration crisis, therefore efficient and effective multi-level governance should be of vital importance. For each one of the four parameters, the main activities are presented with the emphasis on the dialogue among different levels of governance and the problems in cooperation. Additionally, the direction of decision-making was taken into account, with the presentation of the options for inclusion of the subnational level into the decision-making process. Although subnational level forms a part of the multi-level governance model, its inclusion into creating policies is not self-evident and in most cases rather difficult. Data for examination are gathered by the study of the available primary and secondary literature, and accordingly, the vast majority of data represent action plans of the stakeholders involved, press releases and conferences, media interviews and other information obtained from media.

The results are discussed on the basis of the overall assessment based on the theoretical model of predictable challenges of the multi-level governance (Tasan-Kok and Vranken, 2011) and by the shortcomings of the multi-level governance presented by the authors Hurrelmann and DeBardeleben (2009). Tasan-Kok and Vranken (2011) predict applicable challenges first, by including different actors and searching for compromises and balance between them; second, by scrutinizing the hierarchy of the organizations and the need for coordination; third, by screening institutional complexity and the tendency of institutional innovation; and finally, by inspecting the change of aims and objectives of the actors. In contrast, Hurrelmann and DeBardeleben (2009) present the shortcomings of the model itself based on the fundaments of the democratic union. The shortcomings are presented via four sections: congruence dilemma, institutional linkage, participation-deliberation dilemma and effectiveness-accountability dilemma. Through these sections authors expose problems, taking the perspective of the multi-level governance and cooperation when tackling migration crisis.

Furthermore, the research also positions the cooperation among actors when managing migration crisis in one of the two types of multi-level governance introduced by Hooghe and Marks (2003). Type 1 directs responsibility from general to specific with a fixed and long-term authority, while type 2 focuses on specific tasks and flexibility. It should be noted that type 1 is more tra- 
ditional and builds upon the so-called general-purpose governments at different levels, where interactions between these levels and sharing of competences is examined. In the context of EU policy making, this type would actually foresee subnational public actors cooperating with the higher levels in a variety of policy areas. In contrast, type 2 is characterised by task-specific governments, intersecting memberships and a flexible design that is responsive to any emerging temporary needs. In the context of EU policy making, this type would foresee that decision-making and implementation networks take over tasks which are not primarily defined as being important part of EU legislation and politics. Generally, the majority of the cooperation seems to be entrapped with the type 1, but the actors should still seek the governance and cooperation based on the type 2 , since it is a flexible network made out of diverse decision-making bodies to address the issues and tasks of governance at the national and other levels of management with a specialized authority with narrowly defined tasks (Jørgensen and Rosamond, 2001).

In most of the cases, the type 2 is generally integrated into the type 1 , but their mode of operation is quite different. The mode of operation entirely depends on the functioning and willingness of the actors involved, and also on the willingness of community to participate in achieving common goals. Positioning of the multi-level governance of the migration crisis situation into one of two types thus enables the elaboration on how mature and advanced the cooperation among the levels is. On the one hand, by defining multi-level governance as a permanent system of negotiations between nested actors through different levels based on a strong and transparent dialogue, on which external factors rarely affect and the differences in space or geographical distance cannot be marked upon, and on the other hand, by positioning this specific case in one of the two types presented above, enables connecting the two stated theories. Furthermore, this serves as the basis for consideration on possible improvements in the future.

As already noted, mainly qualitative approach is utilised, supplemented with available data and indicators to support the statements, where applicable. In particular, the study is concerned with intergovernmental relations within the policy making process of managing the migrations crisis, although it is slightly biased towards preferring top down perspective, since the analysis of policy implementation and the evaluation of the outcomes of the crisis management represent the main focus of the study. It is worth noting, however, that study focuses solely on the management and policy making during the migration crisis, and it does not specifically address the social and economic consequences of the influx. This is mainly due to the fact that Slovenia is at the focus of the case study, and Slovenia served mainly as a transit country for migrants. This is supported by the data of OECD (2017a), where the data show that it does not serve as a destination country. Namely, if in 2015 there were total 280 asylum seekers in Slovenia, this figure was 890 in 2016 (data for the period 1-9/2016), which indicates that a very tiny share of migrants stopped in Slovenia, even at the peak of the influx. 


\section{Results}

This chapter presents the results of involvement of different levels of government in managing migration crisis. As already noted, Slovenia took a great part in managing the migrant influx on the West Balkan route and by doing so, the national level was exposed to several challenges. In this context, Slovenia has had a great interest to retain its credibility in the international sphere and therefore justify its EU and Schengen zone membership. The migration crisis was basically European problem, and the dialogue between all involved actors was therefore even more important. Furthermore, Slovenia was aware that failure to comply with EU laws and the rules of the Schengen Agreement, as well as non-cooperation, would not be good for solving migration crisis and would hurt the advancement of other Slovenia's interests within the EU. Simultaneously, Slovenia needed also to advance the interests and aspirations of its citizens.

\subsection{Cooperation between supranational and national level}

Supranational level was a target for many complaints for its reactive response from the very beginning on, when it did not focus on providing safe routes to other European countries perceived as destinations for migrants, and in addressing the roots of migration crisis. When Member States independently confronted an unmanageable number of migrants, EU focused on the European migration agenda and on settling operational actions that ought to be settled before. Generally, the operational activities on the national level have been directed towards right direction and proven by numerous endorsements of the EU. Slovenia received support for implementing solutions and was seen as a stable country able to protect the Schengen border and, as such, justified the expectations of the EU (Žnidar, Šefic and But, 2015).

Since the onset of the migration crisis, the supranational level has leveraged solidarity response. National level accepted this policy and performed in accordance with the needs of the arriving migrants, while at the same time ensuring safety and providing normal conditions for its citizens. According to the solidarity response, national level has been preparing for the possible influx through number of activities, including the preparation of the contingency plans. Despite assurances that Slovenia is well prepared for potential upcoming events, it found itself in a chaotic situation and with the inability of a sound management of the migrant influx. A prompt response and support from the supranational level would be expected, however, national level only gradually received financial and human support, more or less only as a result of the request for international assistance. Support arrived from various sources, including other national governments of member states. The supranational level mainly provided the financial assistance in the form of grants aimed towards assisting logistical issues (Republika Slovenija, Vlada RS, 2017), however financial support was not sufficient.

As reception of migrants and registration centres are in the domain of the national level, the supranational level did not interfere in the logistical man- 
agement of the migration crisis. It provided supportive assistance in the form of financial resources, which were also used for the purpose of establishing registration and accommodation centres. The exchange of information and dialogue among supranational and national level focused mostly on the exchange of data on the magnitude of migration and on the solving applications of migrants for international protection.

When the national level started to intensify control at the internal Schengen border with Hungary and started setting up technical barriers on the external Schengen border with Croatia, the supranational level did not interfere and gave the national level basically free possibilities on this issue. All the initiatives and actions were based on understanding of the situation. The border control was firstly adopted for a 10-day period, but afterwards prolonged as the situation did not change and posed a threat to the national security. On the basis of justifiable grounds Slovenia extended its border control for another 20 days, until Hungary closed its borders and the entire migrant wave was redirected to Slovenia (Evropska komisija, 2015). Afterwards, Slovenia followed the idea of other Member States, and started building technical barriers on the external Schengen border with Croatia. Slovenia justified the fence as being a tool to facilitate the direction of the migrant flow and to prevent the uncontrolled passage, meaning that Slovenia actually never closed up its borders.

Furthermore, since the national level obviously did not expect any coordination of the policies regarding the migrant influx, the separate policies were created at the national level to manage crisis situations, that is the current one and potential future ones. Central government passed subsequently in 2016 the so-called International Protection Act, which set the conditions for granting the protection of people entering in Slovenia, and the main purpose of this law was to prepare the country if conditions of migrations are altered, thus causing the security threats to the state and its citizens. Subsequently, even new governmental office was established to deal with migration issues, taking the responsibility from the Ministry of Interior (see OECD, 2017a). Notwithstanding, this indicates problems of multi-level governance within this context, as clear national policies were layered out.

\subsection{Cooperation between national and subnational level}

The most complex issue was actually the cooperation among national and subnational level in Slovenia when managing migration crisis. Namely, there were a lot of problems related to this cooperation. While the national level strived to achieve the EU's expectations and wanted to create normal conditions, the subnational level opinion on the migrant influx and the management of the crisis at the national level was mainly divided, and some dissatisfied social groups gave rise to a public discourse on this issue (Radiotelevizija Slovenija, 2016b).

The lack of dialogue between two levels has been stressed out significantly. The subnational level complained that they didn't have basic information, as 
on which groups of migrants and for how long they would be settled in their municipalities and what is expected from municipalities to do in this situation (Dnevnik, 2016a and Radiotelevizija Slovenija, 2016a). In contrast, the national level rejected the allegations of non-cooperation with the subnational level and creation of inappropriate policies. Additionally, the national level believed that they did inform the subnational level sufficiently and did provide assistance to all municipalities, but it was the decision of municipalities if they accepted this assistance or not (24ur, 2016).

The adoption of a solidarity response at the national level caused divided opinions at the subnational level. Simultaneously, the notion "not in my back yard" gained ground, as citizens of Slovenia would mostly help migrants, but for a limited period and with limited amount of assistance, which was particularly observed in the case of establishment of accommodation centres.

Divided public opinions on the migration crisis were mostly created and shared via social networks. One group demanded from government to change policies, so to open the borders for migrants. In addition, this group disagreed with the return policy, temporary technical barriers at the border, giving additional powers to the Slovenian Armed Forces and the participation of the Slovenian police in Macedonia (Radiotelevizija Slovenija, 2016c). In a sign of disagreement with government decisions, also a petition was formed, which received almost two thousand signatures in total. The petitioners agreed that the government contributes to the fall of humanity through its actions, by raising its dictatorship with non-transparent and non-participatory decision-making, while at the same time allowing the use of public media to create fear and hostility among citizens (Avaaz Community Petitions, 2015). Other group also disagreed with governmental policies, but from a different perspective, also forming petitions. This group was pushing for policies that would try to divert the migrant flows, as this flow was perceived as danger to the border, country and its citizens. Opponents wanted to give a clear signal to the national level that they do not agree with the amount of support that should be allocated to migrants. Additionally, they disagreed with the planning and constructing the accommodation centres in the affected municipalities (Dnevnik, 2016b, Radiotelevizija Slovenija, 2016b, 24ur, 2016, STA, 2016). In essence, media support on this group had more powerful stronger impact on the general public.

Furthermore, several protest rallies were organized at the local level. Most of them took place during February 2016, when the discussion of accommodation centres was at its peak and the resistance against them at the local level was the largest, since the citizens were trying to avoid possibility that accommodation centres would be built in their proximity (Dnevnik, 2016b, Radiotelevizija Slovenija, 2016b, 24ur, 2016, STA, 2016). Interestingly, disagreement was also on establishing technical barriers on the external Schengen border with Croatia, as citizens initiated protest rallies to clearly demonstrate disagreement with the national government decision - mainly, the major problem that was exposed was the negative environmental exter- 
nality of barriers. Namely, technical barriers (i.e., wires etc.) would cause loss of wildlife and would hurt tourism among others (Krope, 2015, E-utrip, 2015, Prava peticija, 2015).

In essence, national government clearly by-passed local governments and residents when creating policies. This was indicated also by the decreasing confidence in central government. Namely, according to the OECD (2017) and Eurobarometer (2017) indicators, Slovenia is one of the countries, where the confidence in central government decreased the most from 2007 onwards. Specifically, public confidence decreased from $48 \%$ in 2007 to $18 \%$ in 2014 , and even further decreased to $17 \%$ in 2017, which is more than 30 percentage points decrease in the period of one decade. Interestingly, although the initial fall from 2007 to 2014 may be attributed mostly to the inefficient economic and fiscal crisis management, it is surprising that confidence remained low and even slightly felt from 2014 to 2017, when at the same time profound economic and fiscal recovery in Slovenia was observed. This suggests that low trust predominantly reflects central government policy making during the migration crisis, as the data for 2017 are gathered mostly in 2016, if we outline basics of both methodologies. Similarly, Freedom House (2017) indicators reveal that National Democratic Score for Slovenia even fell in 2016 (from 2.00 to 2.25) explicitly due to the 2016 migration crisis instability, which served as a main factor contributing to the fall, as the central government was obviously not in control of situation.

\subsection{Cooperation between supranational and subnational level}

There was no direct cooperation between the supranational and subnational level. Actually, supranational level only expected top-down decision making from national level, thereby not perceiving any need to deal with subnational level of government. In contrast, subnational level obviously expected also bottom-up approach when managing migration crisis, and the lack of this approach could be observed through petitions and protests (Dnevnik, 2016b, Radiotelevizija Slovenija, 2016b, 24ur, 2016, STA, 2016).

Interestingly, larger solidarity with migrants was observed at the subnational level, mostly observed through large participation in humanitarian activities (Amnesty International, 2015). Moreover, according to the opinion pool implemented by the Delo newspaper, even during the harshest period of crisis, more than half of the survey respondents were appreciative for the help to migrants and also for accepting them (see Potič, 2016). Similarly, Štrok (2016) has even pointed out that at the street level, the attitudes towards migrants were pretty much the same as to those migrating to and through Slovenia in the early 1990's during the Balkan wars, although the last wave involved mostly persons from other continents and different cultural backgrounds.

Therefore and foremost, the subnational level mostly adopted the European solidarity guidelines, but in the course of its work, it was the only activity where cooperation with national and supranational level was observed. Namely, practically no cooperation could be observed when organizing regis- 
tration and accommodation centres, when establishing additional control at internal borders and when establishing technical barriers on the border with Croatia. It was only expected from subnational level to provide technical support for resolving these issues (Žnidar, Šefic, But, 2015).

\section{Discussion}

As suggested above, the results of the case study analysis indicate that Slovenia has not been properly prepared for managing large-scale crisis. Initially, the real possibility of redirection of the migrant influx towards the territory of Slovenia has not been taken into account by actors, and only later on contingency plan has been prepared at the national level and hands-on management of the crisis has been implemented. The actual occurrence of large migrant wave, combined with the realisation that Slovenia serves only as a transit country for the migrants targeting western and northern European countries, demanded a different approach in managing the crisis. Subsequently, mainly logistical support and coordination of the reception and accommodation centres was required, but their management was mainly marked by time constraints and previously made mistakes.

According to the principles of Tasan-Kok and Vranken (2011), common goals and clear action objectives should be defined and oriented towards the key issues in advance, together with the active participation of the local level, and later on communicated with the other relevant levels. The case study showed mainly unsuccessfulness of the multi-level governance, since it did not contain clear common paths, no clear action plans and no efficient cooperation. For instance, one example of a common goal could be reached by the solidarity response, but it was in practice not established in cooperation with all levels, but only adopted at the national level. Similarly, even the operational activities indicated limited exposure to some common directions. Institutional disconnection caused that the national level created its own response to the crisis. With the subsequent action plans, the EU has logistically cooperated with Slovenia, but consultations were still insufficient, which confirmed the theory of the authors Hurrelmann and DeBardeleben (2009). Institutional disconnection at the subnational level led to the lack of transparency and communication.

Furthermore, the main inconsistency was also observed in the decision-making, which was mostly top-down. This left limited possibility for the involvement of the national and subnational level in decision-making processes in strategical issues. Consequently, it made it difficult for the proper multi-level governance and flexibility at the local level (Tasan-Kok and Vranken, 2011). In this context, potential solution for the greater involvement of the national level in the decision-making process at the supranational level was the initiative of Slovenia, which proposed stopping irregular migration already at the Greek-Macedonian border. This proposal was later on approved and directed by the EU. As far as wider operational cooperation is concerned, we can emphasize a good example of cooperation and integration of the Member 
States on the Western Balkan route, which have created a joint action plan to manage the migration crisis, have co-created the dialogue among them and built additional cooperation on the emerging day-to-day issues. From the operational perspective, the national level experienced managerial flexibility, since the supranational level decided not to interfere. Subnational level did not participate in policy-making processes, since the only domain that local level had was related to logistics management of registration and accommodation centres.

Democratic governance at EU level, which constantly strives for sound decision-making, finds it difficult to achieve coherence in cooperation with actors at the national level. This problem has two ends, and thus no simple solution exists. Namely, the increase of power at the national levels would lead to a differentiating perceptions of the solidarity response and to the variating performance of each Member State, leading to even greater divergence of responses to the migration crisis. In addition, increasing power at the national level would lead to even greater differences between the levels, which would deter the process of multi-level governance from its basic idea. Solution is thus based on creating a compromise among the levels (Hurrelmann and DeBardeleben, 2009).

General principles of the multi-level governance also envisage tight cooperation, well-established communication, shared responsibilities and, not to miss, citizen participation in decision-making (Tasan-Kok and Vranken, 2011). However, the presented results do not support those premises. The problems in cooperation were mainly caused by the lack of dialogue and by the lack of transparency among actors in terms of functioning and decision-making. E.g., in Slovenia, which followed the decisions set out at the supranational level, the level of dissatisfaction of its citizens with national level of government increased, and therefore national level won many criticisms. Many criticisms were based on the lack of cooperation and mutuality. These issues can be attached to the participation-deliberation dilemma, which is already developed within the congruence dilemma. The problem is thus that we have privileged actors who are more easily involved in solving crisis issues, and, on the other hand, actors who cannot be so easily involved or might be even excluded (Hurrelmann and DeBardeleben, 2009).

According to presented results of the case study, multi-level governance in the case of migration crisis on the Western Balkans Route can be positioned as the type 1, if we follow the outline of Marks and Hooghe (2011). The EU's, that is supranational, decision-making architecture is wide and long-term (strategically) oriented. Such architecture is rigid, and the changes are only foreseen with involved actors if necessary, so it is not easy to reach flexible network with all actors, who have mostly narrowly defined tasks, to address the issues and tasks of governance at the national and all other levels.

During the crisis, multi-level governance was not successful, and there was a lack of common response to manage the crisis. This had negative effects on managing the crisis itself, and additionally on the status of the union as a 
whole. Namely, it led to tensions among actors, and the fundaments of union and Schengen area existence were challenged. The lack of cooperation and transparent dialogue has led to the creation of smaller clusters of countries with similar policy positions and interests, which is contradictory to the idea of EU integration. To conclude, the supranational level did call for a more common solution and cooperation, but the guidelines were not integrated in the day-to-day operations (Situation in the Union 2015: Time for Sincerity, Unity and Solidarity, 2015).

What possible recommendations could be delivered from this case study? First, it is evident that the key success factor for managing this kind of situations is government coordination of policies and activities, at all levels. Second, although beyond of the scope of this study, harmonisation of migration policy at the EU (supranational) level is needed, and this involves utilizing proactive approach. This means that both push and pull factors contributing to migrations needed to be taken into the consideration. That is, not just political instability, war situations or climate changes are contributing to migrations as push factors, but we need to address also pull factors that contribute to migrations, such as for example openness of societies in Europe and (national) governmental policies on migrations (i.e., preferring either open or closed "borders"). As PwC (2017) report suggests, we have a matrix of pull factors, that is open/closed borders and open/closed societies nexus. So, in order to prevent future situations like this, it should be uniformly decided, at the supranational level, whether we have open or closed borders, and this should not be subjected to policy-making of particular country. ${ }^{2}$ Furthermore, also our societies need to be prepared for these policies, as open borders with closed societies mean limited approval of migrations and increased social tensions.

\section{Conclusion}

The paper presented the factors of unsuccessfulness of the multi-level governance during the large-scale crisis, as migration crisis on Western Balkan route of 2015-16 can be positioned. As results of the research are based on three parameters, the solidarity response shows among all the highest cooperation among levels. The solidarity response was accepted on the supranational level and the implementation of it was anticipated at all levels. The national level promptly adopted it, but there were some opponents at the local level, who made it harder to properly integrate it. Cooperation on the two parameters of registration and accommodation centres, and on the additional technical controls on the internal Schengen border and building the technical barrier on the external Schengen border, was only observed between national and subnational level via the logistic activities. The cooperation among them presents the major problem as there were many complaints and protest rallies initiated at the local level. The supranational level did not interfere in the logistical decisions of Slovenia and, at the same time, the subnational level was only

2 This has namely contributed to the triggering of the 2015/16 migration crisis. 
involved in operational management, consequently the decision-making was mostly top down. We might even argue, that relations between government levels were decoupled, and to large extend fragmented, which has caused the problem of "layering" of policy creation and implementation.

The research puts forward suggestions for improvement in solving similar large-scale crises in the future. The response to this specific migration crisis was not adequate. The paper reveals several challenges that we can put forward according to Howitt in Leonard (2006), the core ones are recognizing novelty and effectively improvising necessary responses, enabling scalability and surge capacity, maintaining situational awareness, establishing integrated execution in real time, ensuring operational rather than political leadership etc. Improving crisis management in the future would, by authors, involve consolidating four sections: capabilities, structures and systems, people, and coordination.

The research has several limitations when assessing the performance of multi-level governance more generally. First, there is lack of transparency and public accessibility of data on the functioning and decision-making of actors. Second, the functioning of national level differentiates among member states, and in some countries, there is larger role of subnational levels in the decision-making process due to the constitutional provisions. Third, even if the multi-level governance in the case of the migrant crisis was not successful, it does not mean that multi-level governance is unsuccessful in managing other issues, therefore, additional case studies and evaluations are highly warranted. 


\section{References}

24ur. (2016). V Logatcu protestirali proti nastanitvi beguncev in migrantov. At <http://www.24ur.com/novice/slovenija/sefic-o-obvescanju-o-namestitvahmigrantov-izgovor-da-ljudje-niso-seznanjeni-z-dogajanjem-ni-na-mestu.html>, accessed 2 March 2018.

Amnesty International. (2015). Zaščita beguncev: Kaj delajo nevladne organizacije in civilne iniciative, kako se lahko pridružite? At <http://www. amnesty.si/pregled-nvo-begunci>, accessed 2 March 2018.

Avaaz Community Petitions. (2015). Slovenia: For the immediate removal of wire fences on the border with Croatia. At <https://secure.avaaz.org/en/petition/ Government_of_Slovenia_For_the_immediate_removal_of_the_Fenced_ wall_on_the_border_with_Croatia/?selfWjb>, accessed 2 March 2018.

BBC News. (2015). Europe migrants: Tracing perilous Balkan route to Germany. At <http://www.bbc.com/news/world-europe-34039968>, accessed 2 March 2018.

Dnevnik. (2015a). Stojan Jakin, župan občine Vrhnika: Begunci tavajo naokrog in sprašujejo, kje se gre za Ljubljano. At <https://www.dnevnik.si/1042723035>, accessed 2 March 2018.

Dnevnik. (2016b). Protest proti migrantskemu centru v Šenčurju. At <https:// www.dnevnik.si/1042730565>, accessed 2 March 2018.

Eurobarometer (2017). Designing Europe's Future. Special Eurobarometer 461 Report.

E-utrip. (2015). Turistično športno društvo Kostel vabi na protestni pohod od žici na meji ob Kolpi. At <http://www.e-utrip.si/turistino-portno-drutvo-kostelvabi-na-rprotestni-pohod-ob-ici-na-meji-ob-kolpil/>, accessed 2 March 2018.

Evropska komisija. (2015). Mnenje Komisije z dne 23.10.2015 o nujnosti in sorazmernosti ponovne uvedbe nadzora na notranjih mejah s strani Nemčije in Avstrije. At <http://www.europarl.europa.eu/meetdocs/2014_2019/ plmrep/AUTRES_INSTITUTIONS/COMM/COM_11B/2015/12-21/ COM_C(2015)7100_SL.pdf>, accessed 2 March 2018.

Freedom House (2017). Nations in Transit. 2017 Report.

Frontex. (2017). Migratory routes map. At <http://frontex.europa.eu/trends-androutes/migratory-routes-map/>, accessed 2 March 2018.

Hooghe, L. (1996). Cohesion Policy and European Integration. Building MultiLevel Governance. Oxford: Oxford University Press.

Hooghe, L. and Marks, G. (2003). Unravelling the Central State, but how? Types of Multi-level governance. The American Political Science Review, 97(2), pp. 233-243.

Howitt, A. M. and Leonard, H.B. (2006). Beyond Katrina: Improving Disaster Response Capabilities. Cambridge: Hadvard University.

Hurrelmann, A. and DeBardeleben, J. (2009). Democratic Dilemmas in EU Multilevel Governance: Untangling the Gordian Knot. European Political Science Review, 1(2), pp. 229-247.

Jørgensen, K.E. and Rosamond, B. (2001). Europe: Regional Laboratory for a Global Polity? Warwick: Centre for the Study of Globalization and Regionalization.

Jørgensen, M.B. (2012). The diverging logics of integration policy making at national and city level. International Migration Review, 46(1), pp. 244-278. 
Kluvankova-Oravska, T. and Chobotova, V. (2010). The Emergence of Multilevel Governance. The Case of the Biodiversity in the Enlarged European Union. Ekonomicky časopis, 58(4), pp. 407-422.

Krope, F. S. (2015). Bodo zaščitne terenske ovire v prihodnje del vsakdanjika? Lovec, 99(1), pp. 4-5.

Kull, M. and Tatar, M. (2015). Multi-Level Governance in A Small State - A Study on Involvement, Participation, Partnership, and Subsidiarity. Regional \& Federal Studies, 25(3), pp. 229-257.

Marks, G. (1993). Structural Policy and Multilevel Governance in the EC. In A. Cafruny and G. G. Rosenthal, ed., Structural Policy and Multilevel Governance. Harlow: Longman, pp. 391-409.

OECD (2017). Government at Glance. Paris: OECD.

OECD (2017a). International Migration Outlook. Paris: OECD.

Potič, Z. (2016). Dobra polovica naklonjena sprejetju prosilcev za azil. Delo, March 21, 2016.

Prava peticija (2017). Žica ob Kolpi-MI SMO PROTI. At <https://www. pravapeticija.com/ica_ob_kolpi-kostel_je_proti>, accessed 2 March 2018.

PwC (2017). Managing the refugee and migrant crisis: the role of governments, private sector and technology. PwC Global Crisis Centre Report.

Radiotelevizija Slovenija. (2016a). V Ljubljano prispeli prvi prosilci za azil; v Logatcu protestni shod. At <https://www.rtvslo.si/slovenija/v-ljubljanoprispeli-prvi-prosilci-za-azil-v-logatcu-protestni-shod/386543>, accessed 2 March 2018.

Radiotelevizija Slovenija. (2016b). Dva protesta najavljena v Ljubljani, en na Vrhniki. At <https://www.rtvslo.si/slovenija/dva-protesta-najavljena-vljubljani-en-na-vrhniki/386706>, accessed 2 March 2018.

Radiotelevizija Slovenija. (2016c). V Ljubljani shod proti fašizmu in v podporo beguncem. At<https://www.rtvslo.si/slovenija/v-ljubljani-shod-proti-fasizmuin-v-podporo-beguncem/388604>, accessed 2 March 2018.

Republika Slovenija, Ministrstvo za notranje zadeve RS, Policija. (2016a). Podatki o številu migrantov, ki so vstopili v Slovenijo do 11. marca 2016 do 6. ure. At <http://www.policija.si/index.php/component/content/article/35-sporocilaza-javnost/83363-podatki-o-tevilu-migrantov-ki-so-vstopili-v-slovenijo-do-11marca-2016-do-6>, accessed 2 March 2018.

Republika Slovenija, Ministrstvo za notranje zadeve RS, Policija. (2015). Podatki o številu migrantov, ki so vstopili v Slovenijo do 31. decembra do 6. ure (popravek!). At <http://www.policija.si/index.php/component/content/ article/35-sporocila-za-javnost/82347-podatki-o-tevilu-migrantov-ki-sovstopili-v-slovenijo-do-31-decembra-do-6-ure>, accessed 2 March 2018.

Republika Slovenija, Ministrstvo za notranje zadeve. (2017b). Število prosilcev za mednarodno zaščito 2015. At <http://www.mnz.gov.si/si/mnz_za_vas/tujci_v_ sloveniji/statistika/>, accessed 2 March 2018.

Republika Slovenija, Ministrstvo za notranje zadeve. (2017c). Število prosilcev za mednarodno zaščito 2016. At <http://www.mnz.gov.si/si/mnz_za_vas/tujci_v_ sloveniji/statistika/>, accessed 2 March 2018.

Republika Slovenija, Vlada RS. (2017). Pomoč iz tujine. At <http://www.vlada.si/ pomoc_beguncem/pomoc_iz_tujine/>, accessed 2 March 2018.

Scholten, P. and Penninx, R. (2016). The Multilevel Governance of Migration and Integration. In B. Garces-Mascareñas and R. Penninx, eds., Integration 
Processes and Policies in Europe. IMISCOE Research Series. Cham: Springer Open, pp. 91-108.

STA. (2016). V Lenartu 200 protestnikov proti migrantom, Brglez pozval k dialogu. At <https://www.sta.si/2235776/v-lenartu-200-protestnikov-protimigrantom-brglez-pozval-k-dialogum>, accessed 2 March 2018.

Stephenson, P. (2013). Twenty years of multi-level governance: 'Where Does It Come From? What Is It? Where Is It Going?'. Journal of European Public Policy, 20(6), pp. 817-837.

Štrok, L. (2016). Javno mnenje o migrantih in beguncih v RS. Ljubljana: FVV.

Tanimura, K. and Yoshikawa, K. (2014). Crisis Management System for Largescale Disasters. Hitachi Review, 63(5), pp. 35-39.

Tasan, K. T. and Vranken, J. (2011). Handbook for Multilevel Urban Governance in Europe. The Hague: European Urban Knowledge Network.

US Department of Homeland Security. (2017). National Incident Management System. Washington DC: FEMA.

Young European Federalists. (2016). Young European Federalists demand: "Don't touch my Schengen". At <https://www.thenewfederalist.eu/youngeuropean-federalists-demand-don-t-touch-my-schengen>, accessed 2 March 2018.

Zincone, G. and Caponio, T. (2004). The multilevel governance of migration: State of the art report Cluster C9. IMISCOE general conference, 3rd-4th December 2004, Coimbra. At <https://pdfs.semanticscholar.org/bedd/9056daa8e48a69 40c945e35429d4c56b59d0.pdf>, accessed 16 April 2018.

Žnidar, G. V., Šefic, B. and But, D. (2015). Novinarska konferenca o aktualnem dogajanju v zvezi s prihodom beguncev oz. migrantov (video conference). At <http://www.vlada.si/medijsko_sredisce/video/video/article/novinarska_ konferenca_o_aktualnem_dogajanju_v_zvezi_s_prihodom_beguncev_oz_ migrantov_55915/>, accessed 2 March 2018. 